\title{
Introduction to the French GEOTRACES North Atlantic Transect (GA01): GEOVIDE cruise
}

Géraldine Sarthou ${ }^{1}$, Pascale Lherminier ${ }^{2}$, Eric P. Achterberg ${ }^{3}$, Fernando Alonso-Pérez ${ }^{4}$, Eva Bucciarelli ${ }^{1}$, Julia Boutorh $^{1}$, Vincent Bouvier ${ }^{5}$, Edward A. Boyle ${ }^{6}$, Pierre Branellec ${ }^{2}$, Lidia I. Carracedo ${ }^{4}$, Nuria Casacuberta ${ }^{7}$, Maxi Castrillejo ${ }^{7,8}$, Marie Cheize ${ }^{1, a}$, Leonardo Contreira Pereira ${ }^{9}$, Daniel Cossa ${ }^{10}$, Nathalie Daniault ${ }^{2}$, Emmanuel De Saint-Léger ${ }^{11}$, Frank Dehairs ${ }^{12}$, Feifei Deng ${ }^{13}$, Floriane Desprez de Gésincourt ${ }^{1,2}$, Jérémy Devesa ${ }^{1}$, Lorna Foliot $^{14}$, Debany Fonseca-Batista ${ }^{12,15}$, Morgane Gallinari ${ }^{1}$, Maribel I. García-Ibáñez ${ }^{4,16}$, Arthur Gourain ${ }^{1,17}$, Emilie Grossteffan ${ }^{18}$, Michel Hamon ${ }^{2}$, Lars Eric Heimbürger ${ }^{19}$, Gideon M. Henderson ${ }^{13}$, Catherine Jeandel ${ }^{5}$, Catherine Kermabon ${ }^{2}$, François Lacan ${ }^{5}$, Philippe Le Bot ${ }^{2}$, Manon Le Goff ${ }^{1}$, Emilie Le Roy ${ }^{5}$, Alison Lefèbvre ${ }^{2}$, Stéphane Leizour $^{2}$, Nolwenn Lemaitre ${ }^{1,12, b}$, Pere Masquée ${ }^{8,20,21}$, Olivier Ménage ${ }^{2}$, Jan-Lukas Menzel Barraqueta ${ }^{3, c}$, Herlé Mercier ${ }^{2}$, Fabien Perault ${ }^{11}$, Fiz F. Pérez ${ }^{4}$, Hélène F. Planquette ${ }^{1}$, Frédéric Planchon ${ }^{1}$, Arnout Roukaerts ${ }^{12}$, Virginie Sanial $^{5, \mathrm{~d}}$, Raphaëlle Sauzède ${ }^{22}$, Catherine Schmechtig ${ }^{23}$, Rachel U. Shelley ${ }^{1, \mathrm{e}}$, Gillian Stewart ${ }^{24,25}$, Jill N. Sutton ${ }^{1}$, Yi Tang ${ }^{25,24}$, Nadine Tisnérat-Laborde ${ }^{14}$, Manon Tonnard ${ }^{1,26,27}$, Paul Tréguer ${ }^{1}$, Pieter van Beek ${ }^{5}$, Cheryl M. Zurbrick ${ }^{6}$, and Patricia Zunino ${ }^{2}$

${ }^{1}$ LEMAR (Laboratoire des Sciences de l'environnement marin), CNRS, Univ. Brest, IRD, Ifremer,

Technopôle Brest-Iroise, 29280 Plouzané, France

${ }_{2}^{2}$ Ifremer, Univ. Brest, CNRS, IRD, Laboratoire d'Océanographie Physique et Spatiale (LOPS), IUEM, Plouzané, France

${ }^{3}$ GEOMAR Helmholtz Centre for Ocean Research Kiel, 24148 Kiel, Germany

${ }^{4}$ Instituto de Investigaciones Marinas, IIM-CSIC, Eduardo Cabello 6, 36208 Vigo, Spain

${ }^{5}$ LEGOS (Laboratoire d'Etudes en Géophysique et Océanographie Spatiales), Université de Toulouse,

CNES, CNRS, IRD, UPS, 14 Avenue Edouard Belin, 31400 Toulouse, France

${ }^{6}$ Earth, Atmospheric and Planetary Sciences, Massachusetts Institute of Technology, Cambridge, MA 02139, USA

${ }^{7}$ Laboratory of Ion Beam Physics, Department of Earth Sciences, Institute of Geochemistry and Petrology, ETH-Zurich, Otto Stern Weg 5, Zurich, 8093, Switzerland

${ }^{8}$ Institut de Ciència i Tecnologia Ambientals \& Departament de Física, Universitat Autònoma de Barcelona, 08193 Bellaterra, Spain

${ }^{9}$ Laboratório de Hidroquímica-IO/FURG, Rio Grande, Brazil

${ }^{10}$ ISTerre, Université Grenoble Alpes, CS 40700, 38058 Grenoble, CEDEX 9, France

${ }^{11} \mathrm{CNRS}$, INSU, Division Technique Bâtiment IPEV - Centre Ifremer, Technopôle Brest-Iroise, CS 50074, 29280 Plouzané, France

${ }^{12}$ Analytical, Environmental and Geo-Chemistry, Vrije Universiteit Brussel, Pleinlaan 2, 1050, Brussels, Belgium

${ }^{13}$ Department of Earth Sciences, University of Oxford, South Parks Road, Oxford, OX1 3AN, UK

${ }^{14}$ LSCE/IPSL-CEA-CNRS-UVSQ-Université Paris Saclay, Gif-sur-Yvette, F-91198 CEDEX, France

${ }^{15}$ Department of Biology, Dalhousie University, Halifax, Nova Scotia, B3H 4R2, Canada

${ }^{16}$ Uni Research Climate, Bjerknes Centre for Climate Research, Bergen 5008, Norway

${ }^{17}$ Ocean Sciences Department, School of Environmental Sciences, University of Liverpool, Liverpool, L69 3GP, UK

${ }^{18}$ IUEM, UMS 3113, CNRS, Univ. Brest, IRD, Ifremer, Technopôle Brest Iroise,

rue Dumont d'Urville, 29280 Plouzané, France

${ }^{19}$ Aix Marseille Université, CNRS/INSU, Université de Toulon, IRD, Mediterranean Institute of

Oceanography UM 110, Marseille, France

${ }^{20}$ School of Science, Edith Cowan University. 270 Joondalup Drive, Joondalup, WA 6027, Australia

${ }^{21}$ Oceans Institute \& Department of Physics, School of Physics, Mathematics and Computing, University of Western

Australia, Crawley, WA 6009, Australia

Published by Copernicus Publications on behalf of the European Geosciences Union. 
${ }^{22}$ Sorbonne Universités, UPMC Univ Paris 06, CNRS, Laboratoire d'Océanographie de Villefranche (LOV), 06230 Villefranche-sur-Mer, France

${ }^{23}$ Sorbonne Université, CNRS, UMS 3455, OSU Ecce-Terra, Paris Cedex 5, France

${ }^{24}$ School of Earth and Environmental Sciences, Queens College, City University of New York, Flushing, USA

${ }^{25}$ Earth and Environmental Sciences, the Graduate Center, City University of New York, New York, USA

${ }^{26}$ Antarctic Climate and Ecosystem Cooperative Research Centre (ACE CRC), University of Tasmania,

Private Bag 80, Hobart, TAS 7001, Australia

${ }^{27}$ Institute for Marine and Antarctic Studies, University of Tasmania, Hobart, TAS 7001, Australia

${ }^{\mathrm{a}}$ currently at: Laboratoire des cycles géochimiques, Géosciences Marines, Centre Ifremer Bretagne, Plouzané, France

${ }^{b}$ currently at: Department of Earth Sciences, Institute of Geochemistry and Petrology, ETH Zurich, Zürich, Switzerland

${ }^{c}$ currently at: Department of Earth Sciences, Stellenbosch University, Stellenbosch, 7600, South Africa

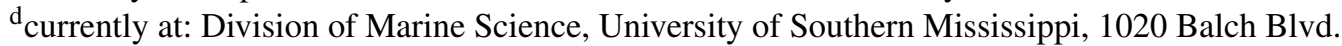

Stennis Space Center, MS 39529, USA

${ }^{\mathrm{e}}$ currently at: Earth, Ocean and Atmospheric Science, Florida State University, Tallahassee, Florida 32306, USA

Correspondence: Géraldine Sarthou (geraldine.sarthou@univ-brest.fr)

Received: 29 June 2018 - Discussion started: 20 July 2018

Revised: 16 October 2018 - Accepted: 30 October 2018 - Published: 29 November 2018

\begin{abstract}
The GEOVIDE cruise, a collaborative project within the framework of the international GEOTRACES programme, was conducted along the French-led section in the North Atlantic Ocean (Section GA01), between 15 May and 30 June 2014. In this special issue (https://www.biogeosciences.net/special_issue900.html), results from GEOVIDE, including physical oceanography and trace element and isotope cyclings, are presented among 18 articles. Here, the scientific context, project objectives, and scientific strategy of GEOVIDE are provided, along with an overview of the main results from the articles published in the special issue.
\end{abstract}

\section{Scientific context and objectives}

Understanding the distribution, sources, and sinks of trace elements and isotopes (TEIs) will improve our ability to understand past and present marine environments. Some TEIs are toxic (e.g. $\mathrm{Hg}$ ), while others are essential micronutrients involved in many metabolic processes of marine organisms (e.g. Fe, Mn). The availability of TEIs therefore constrains the ocean carbon cycle and affects a range of other biogeochemical processes in the Earth system, whilst responding to and influencing global change (de Baar et al., 2005; Blain et al., 2007; Boyd et al., 2007; Pollard et al., 2007). Moreover, TEI interactions with the marine food web strongly depend on their physical (particulate/dissolved/colloidal/soluble) and chemical (organic and redox) forms. In addition, some TEIs are diagnostic in allowing the quantification of specific mechanisms in the marine environment that are challenging to measure directly. A few examples include (i) atmospheric deposition (e.g. ${ }^{210} \mathrm{~Pb}, \mathrm{Al}$,
Mn, Th isotopes, ${ }^{7} \mathrm{Be}$; Baker et al., 2016; Hsieh et al., 2011; Measures and Brown, 1996); (ii) mixing rates of deep waters or shelf-to-open ocean (e.g. ${ }^{231} \mathrm{~Pa} /{ }^{230} \mathrm{Th}, \Delta{ }^{14} \mathrm{C}$, Ra isotopes, ${ }^{129} \mathrm{I},{ }^{236} \mathrm{U}$; van Beek et al., 2008; Casacuberta et al., 2016; Key et al., 2004); (iii) boundary exchange processes (e.g. $\varepsilon_{\mathrm{Nd}}$, Jeandel et al., 2011; Lacan and Jeandel, 2001, 2005); and (iv) downward flux of organic carbon and/or remineralization in deep waters (e.g. ${ }^{234} \mathrm{Th} /{ }^{238} \mathrm{U},{ }^{210} \mathrm{~Pb} /{ }^{210} \mathrm{Po}, \mathrm{Ba}_{\mathrm{xs}}$; Buesseler et al., 2004; Dehairs et al., 1997; Roca-Martí et al., 2016). In such settings, TEIs provide chemical constraints and allow the estimation of fluxes which was not possible before the development of their analyses. Finally, paleoceanographers are wholly dependent on the development of tracers, many of which are based on TEIs used as proxies, in order to reconstruct past environmental conditions (e.g. ocean productivity, patterns and rates of ocean circulation, ecosystem structures, ocean anoxia; Henderson, 2002). Such reconstruction efforts are essential to assess the processes involved in regulating the global climate system, and possible future climate change variability.

Despite all these major implications, the distribution, sources, sinks, and internal cycling of TEIs in the oceans are still largely unknown due to the lack of appropriate clean sampling approaches and insufficient sensitivity and selectivity of the analytical measurement techniques until recently. This last point has improved very quickly as significant improvements in the instrumental techniques now allow the measurements of concentrations, speciation (physical and chemical forms), and isotopic compositions for most of the elements of the periodic table which have been identified either as relevant tracers or key nutrients in the marine environment. These recent advances provide the marine geochemistry community with a significant opportunity to make sub- 


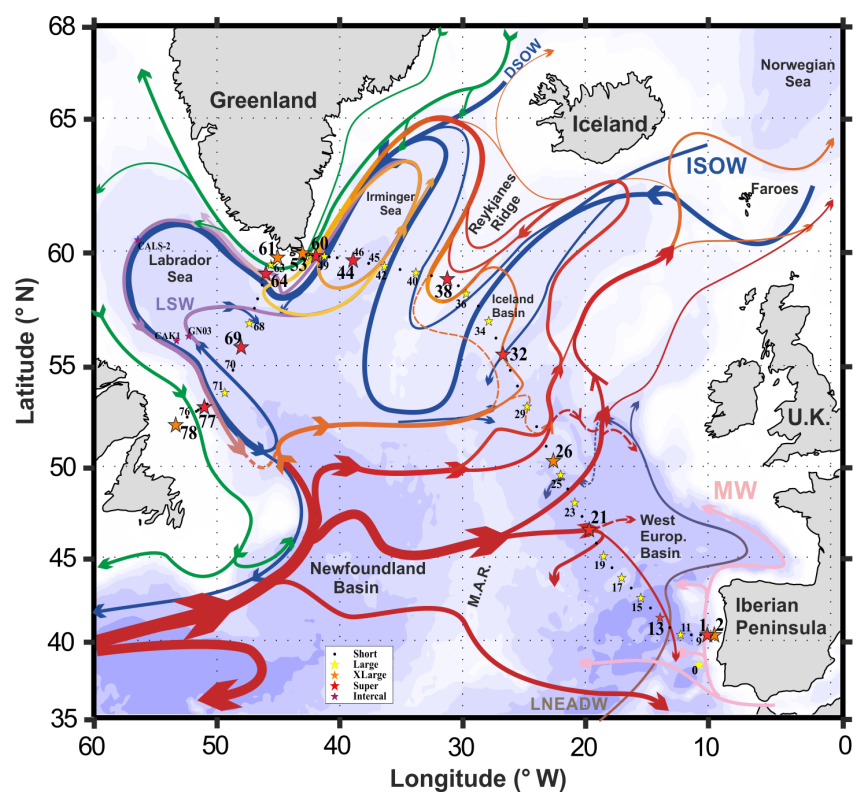

Figure 1. Schematic diagram of the mean large-scale circulation adapted from Daniault et al. (2016) and Zunino et al. (2017). Bathymetry is plotted in color with color changes at 100 and $1000 \mathrm{~m}$ and every $1000 \mathrm{~m}$ below $1000 \mathrm{~m}$. Black dots represent the Short station, yellow stars the Large ones, orange stars the XLarge ones, and red stars the Super ones. The main water masses are indicated: Denmark Strait Overflow Water (DSOW), Iceland-Scotland Overflow Water (ISOW), Labrador Sea Water (LSW), Mediterranean Water (MW), and lower North East Atlantic Deep Water (LNEADW).

stantial contributions to a better understanding of the marine environment.

In this general context, the aim of the international GEOTRACES programme is to characterize TEI distributions on a global scale, consisting of ocean sections, and regional process studies, using a multi-proxy approach. The GEOVIDE section is the French contribution to this global survey in the North Atlantic Ocean along the OVIDE section and in the Labrador Sea (Fig. 1) and complements a range of other international cruises in the North Atlantic. GEOVIDE leans on the knowledge gained by the OVIDE project during which the Portugal-Greenland section has been carried out biennially since 2002, gathering physical and biogeochemical data from the surface to the bottom (Mercier et al., 2015; Pérez et al., 2018).

\section{Rationale for the GEOVIDE section}

i. The North Atlantic Ocean plays a key role in mediating the climate of the Earth. It represents a key region of the Meridional Overturning Circulation (MOC) and a major sink of anthropogenic carbon $\left(\mathrm{C}_{\mathrm{ant}}\right)$ (Pérez et al., 2013; Sabine et al., 2004; Seager et al., 2002). Since 2002, the OVIDE project has contributed to the observation of both the circulation and water mass proper- ties of the North Atlantic Ocean. Despite the importance of the MOC on global climate, it is still challenging to assess its strength within a reasonable uncertainty (Kanzow et al., 2010; Lherminier et al., 2010). The MOC strength estimated from in situ measurements on OVIDE cruises has thus helped to validate a time series for the amplitude of the MOC (based on altimetry and ARGO float array data) that exhibits a drop of $2.5 \pm 1.4 \mathrm{~Sv}$ (95\% confidence interval) between 1993 and 2010 (Mercier et al., 2015), consistent with other modelling studies (Xu et al., 2013). This time series, along with the in situ data, shows a recovery of the MOC amplitude in 2014 at a value similar to those of the mid1990s, confirming the importance of the decadal variability in the subpolar gyre. During OVIDE, the contributions of the most relevant currents, water masses, and biogeochemical provinces were localized and quantified. This knowledge was crucial for the establishment of the best strategy to sample TEIs in this specific region.

In addition to the OVIDE section, the Labrador Sea section offered a unique opportunity to complement the MOC estimate, to analyse the propagation of anomalies in temperature and salinity (Reverdin et al., 1994), and to study the distribution of TEIs along the boundary current of the subpolar gyre, coupling both observations and modelling.

Moreover, recent results provided evidence that $\mathrm{CO}_{2}$ uptake in the North Atlantic was reduced by the weakening of the MOC (Pérez et al., 2013). The most significant finding of this study was that the uptake of $\mathrm{C}_{\mathrm{ant}}$ occurred almost exclusively in the subtropical gyre, while natural $\mathrm{CO}_{2}$ uptake dominated in the subpolar gyre. In light of these new results, one issue to be addressed was the coupling between the $\mathrm{C}_{\text {ant }}$ and the transport of water, with the aim to understand how the changes in the ventilation and in the circulation of water masses affect the $\mathrm{C}_{\mathrm{ant}}$ uptake and its storage capacity in the various identified provinces (Fröb et al., 2018).

Finally, as the subpolar North Atlantic forms the starting point for the global ocean conveyor belt, it is of particular interest to investigate how TEIs are transferred to the deep ocean through both ventilation and particle sinking, and how deep convection processes impact the TEI distributions in this key region.

ii. A better assessment of the factors that control organic production and export of carbon in the productive North Atlantic Ocean together with a better understanding of the role played by TEIs in these processes is research priorities. Pronounced phytoplankton blooms occur in the North Atlantic in spring in response to upwelling and water column destratification (Bury et al., 2001; Henson et al., 2009; Savidge et al., 1995). Such 
blooms are known to trigger substantial export of fastsinking particles (Lampitt, 1985), and can represent a major removal mechanism for particulate organic carbon, macronutrients, and TEIs to the deep ocean.

iii. In the North Atlantic, TEI distributions are influenced by a variety of sources including, most importantly, the atmosphere and the margins (Iberian, Greenland, and Labrador margins).

1. Atmosphere. Atmospheric inputs (e.g. mineral dust, anthropogenic emission aerosols) are an important source of TEIs to the North Atlantic Ocean due to the combined effects of anthropogenic emissions from industrial/agricultural sources and mineral dust mobilized from the arid regions of North Africa (Duce et al., 2008; Jickells et al., 2005). Model and satellite data for the GEOVIDE section suggested that an approximately 10fold decrease in the atmospheric concentrations of mineral dust was expected from south to north (Mahowald et al., 2005). As there had been relatively few aerosol TEI studies in the northern North Atlantic compared to the tropical and subtropical North Atlantic prior to GEOVIDE, constraining atmospheric deposition fluxes to this region had been identified as a research priority (de Leeuw et al., 2014). During the GEOVIDE campaign, a multi-proxy approach (e.g. aerosol trace element concentrations, dissolved and particulate $\mathrm{Al}$ and $\mathrm{Mn}$, seawater ${ }^{210} \mathrm{~Pb}, \mathrm{Fe}, \mathrm{Nd}$, and Th isotopes, ${ }^{7} \mathrm{Be}$ ) was taken to achieve the objective of better constraining the atmospheric deposition fluxes of key trace elements.

2. Margins. The continental shelves can act as a filter for TEIs supplied from shelf sediments, submarine groundwater discharge (including the discharge of fresh groundwater into the coastal seas and recirculation of seawater through the sediment), and rivers. While some TEIs are removed on the continental shelves, others are thought to be mobilized from the solid phase at the land-ocean interface (e.g. Fe and likely other microand macronutrients, such as $\mathrm{Cu}, \mathrm{Ni}, \mathrm{Mn}$, and $\mathrm{Si}$; Chase et al., 2005; Jeandel and Oelkers, 2015). The cruise track intersected several margins, thus allowing for the characterization of continental sources and quantification of TEI fluxes associated with these sources in various shelf regimes.

iv. It is obviously needed to further validate the use of paleoproxies. For example, in recent years, the potential of the ${ }^{231} \mathrm{~Pa} /{ }^{230} \mathrm{Th}$ ratio for identifying past rates of ocean circulation, and of the isotopic composition of neodymium $\left(\varepsilon_{\mathrm{Nd}}\right)$ as a tracer of thermohaline circulation, has led to many paradigm-changing results for the reconstitution of the Atlantic Ocean circulation (McManus et al., 2004; Montero-Serrano et al., 2013; Negre et al., 2010). However, there is an ongoing debate about the interpretation of ${ }^{231} \mathrm{~Pa} /{ }^{230} \mathrm{Th}$ paleo-records in the Atlantic (Hayes et al., 2015; Keigwin and Boyle, 2008) focused on the effects of particle fluxes versus those of water circulation. Only one single ${ }^{231} \mathrm{~Pa}$ profile in the subpolar North Atlantic was published before GEOVIDE (Moran et al., 2002). Regarding Nd isotopes, although several profiles of dissolved (and total) $\mathrm{Nd}$ isotopes are available in the boundary currents of Greenland and the Labrador Sea, there are very few profiles for the ocean interior of the GEOVIDE region (Copard et al., 2011; Filippova et al., 2017; Lacan and Jeandel, 2004; Lambelet et al., 2016). In addition, the importance of the interactions between the dissolved and the particulate phases in the control of the isotopic composition of $\mathrm{Nd}$ is becoming increasingly apparent. To the best of our knowledge, particulate $\varepsilon_{\mathrm{Nd}}$ data have not been published yet for the subpolar North Atlantic. For these reasons, documentation of these tracers in both dissolved and particulate phases is needed to provide new constraints and to significantly advance our understanding of the cycles of these tracers and their use in the modern and past oceans. Furthermore, proxies of nutrient utilization, such as the silicon stable isotopes $\left(\delta^{30} \mathrm{Si}\right)$ from diatom silica, provide a means of reconstructing the behaviour of past geochemical cycles and the past strength of the biological pump, and its influence on atmospheric concentrations of $\mathrm{CO}_{2}$. However, successful application of $\delta^{30} \mathrm{Si}$ in diatoms accumulating in sediments for the reconstruction of past silica cycling requires a thorough understanding of $\delta^{30} \mathrm{Si}$ of dissolved $\mathrm{Si}\left({ }^{30} \mathrm{Si}_{\mathrm{DSi}}\right)$ and of the processes that control its distribution throughout the modern ocean. Combining studies in the Southern Ocean (De La Rocha et al., 2011; Fripiat et al., 2011) and North and Equatorial Pacific (De La Rocha et al., 2000) with a global circulation model (Wischmeyer et al., 2003) has revealed the roles that ocean circulation and biogeochemical cycling play in controlling the distribution of silicon isotopes within the ocean. Largely missing from this dataset was the North Atlantic Ocean (De La Rocha et al., 2011).

In this general context, the main scientific objectives of GEOVIDE were to (i) better understand and quantify the MOC and the carbon cycle carbon cycle in the context of decadal variability, adding new tracers to this end; (ii) map the TEI distributions, including their physical and chemical speciation, along this full-depth high-resolution ocean section; (iii) investigate the links between TEIs and the production, export, and remineralization of particulate organic matter; (iv) identify TEI sources and sinks, and quantify their fluxes at the ocean boundaries; and (v) better understand and quantify the paleoproxies ${ }^{231} \mathrm{~Pa} /{ }^{230} \mathrm{Th}, \varepsilon_{\mathrm{Nd}}$, and $\delta^{30} \mathrm{Si}$. 


\section{Strategy}

To achieve the objectives of the GEOVIDE project, a 47day multidisciplinary cruise was carried out on board N/O Pourquoi Pas? in the North Atlantic Ocean along the OVIDE section, from Lisbon to Greenland, and in the Labrador Sea (Fig. 1). The Labrador section was chosen according to the OSNAP (Overturning in the Subpolar North Atlantic Programme) recommendations because it transects the export route of the Labrador Sea Water downstream of its formation site. Therefore, the properties of the North Atlantic Deep Water (NADW) at $53^{\circ} \mathrm{N}$ are likely to be representative of NADW further south and a 15-year time series of currents and hydrographic properties is available in the western boundary current at this latitude (Fischer et al., 2010). The GEOVIDE cruise took place from 15 May to 30 June 2014, during the same season as the previous OVIDE cruises (2002-2012). The cruise timing helped to minimize seasonal variations and maximize the representativeness of inter-annual variability of the physical parameters investigated in this specific region. Furthermore, this period of the year corresponds to the bloom/post-bloom period of the subpolar gyre and post-bloom period in the subtropical gyre (Henson et al., 2009), thus allowing for the study of the complexity of the biological pump and the links between production, export of organic matter, and TEIs.

A high-resolution hydrographical section that includes the in situ measurements of the currents by doppler profilers was performed and, as recommended by GEOTRACES, a multiproxy approach was used. In total, 78 stations were occupied (plus one test station). Station naming depended on the number of casts that were conducted: Short (47 one-cast stations), Large (17 three-cast stations), XLarge (5 five-cast stations), and Super (10 multi-cast stations). A total of 341 on-deck operations were carried out during GEOVIDE.

In total, (i) the standard stainless steel rosette was deployed 163 times, (ii) the trace metal clean rosette, 53 times, (iii) in situ pumps, 25 times, (iv) the mono-corer, with or without in situ pumps clamped on the cable, 11 times, and (v) the plankton net, 9 times. We also collected 140 surface seawater samples using a fish towed from the ship's starboard side and deployed at 1-2 m depth, 18 aerosol samples, and 10 rainwater samples. In addition, we deployed 60 eXpendable BathyThermographs (XBTs), 17 ARGO profiling floats (8 ARVOR, 2 ARVOR-deep, 2 PROVOR-DO, 2 PROVBIO, 1 ARVOR double DO, and 2 APEX), and 12 weather buoys.

\section{Summary of the main results published in this special issue}

In this special issue, 18 publications present results of the GEOVIDE project. Six other articles have already been published in other journals (Benetti et al., 2017; Cossa et al., 2018b; Le Reste et al., 2016; Pérez et al., 2018; Shelley et al., 2017; Zunino et al., 2015). Due to the long time required for some analyses, other articles related to this project are to be expected for publication at a later date.

The articles in this special issue are linked to four general research themes: (i) hydrographic and physical characteristics; (ii) links between water masses and TEIs; (iii) external sources and sinks of TEIs; and (iv) biogeochemical tracers of community structure, export, and remineralization.

\subsection{Hydrographic and physical characteristics}

In terms of circulation, the comparison with the 2002-2012 mean state shows a different repartition of the northward warm currents that compose the upper limb of the MOC, with a more intense Irminger Current (station 39-41) and a weaker North Atlantic Current (NAC) in the West European Basin, these anomalies being compatible with the variability previously observed along the OVIDE section in the 2000s (Zunino et al., 2017). The distribution of the volume transport in the three branches of the NAC (Fig. 1) has changed: no transport was found in the northern branch, although $11 \mathrm{~Sv}$ was found in the mean of the previous decade, and the central branch, which marks the limit between the subpolar and the subtropical regions, nearly doubled in 2014.

The main hydrographic properties along the GEOVIDE section are shown in Fig. 2 for potential temperature, salinity, dissolved oxygen, nitrate + nitrite, and silicic acid. The surface waters of the eastern SPNA, down to about $500 \mathrm{~m}$, were much colder and fresher than the average values observed over 2002-2012 (Zunino et al., 2017). In the context of the ocean heat loss observed in the subpolar gyre since 2005 , the year 2013-2014 was indeed particularly intense. Remarkably, despite the negative temperature anomalies in the surface waters, the heat transport across the OVIDE section estimated during GEOVIDE was the largest measured since 2002. This was attributed to the relatively strong MOC measured across the OVIDE section during GEOVIDE (Zunino et al., 2017) and more particularly to the strong transport of central water in the central and southern branch of the NAC (García-Ibáñez et al., 2018) that compensates the cold anomaly of the surface layer. The relatively strong MOC and heat transport were confirmed by Holliday et al. (2018) across a nearly simultaneous section (June-July 2014) between Labrador and Scotland.

The water mass properties of the GEOVIDE cruise were used to perform an extended Optimum MultiParameter (eOMP) analysis and to assess the water mass distribution (García-Ibáñez et al., 2018). The eOMP analysis together with the absolute geostrophic velocity field, determined using a box inverse model, allowed the evaluation of the relative importance of each water mass to the MOC. The increase in the MOC intensity from 2002-2010 to 2014 was shown to be related to the increase in the northward transport of the central waters in its upper limb (from the surface to $1000 \mathrm{~m}$ in the south-eastern part of the section), and in the southward 

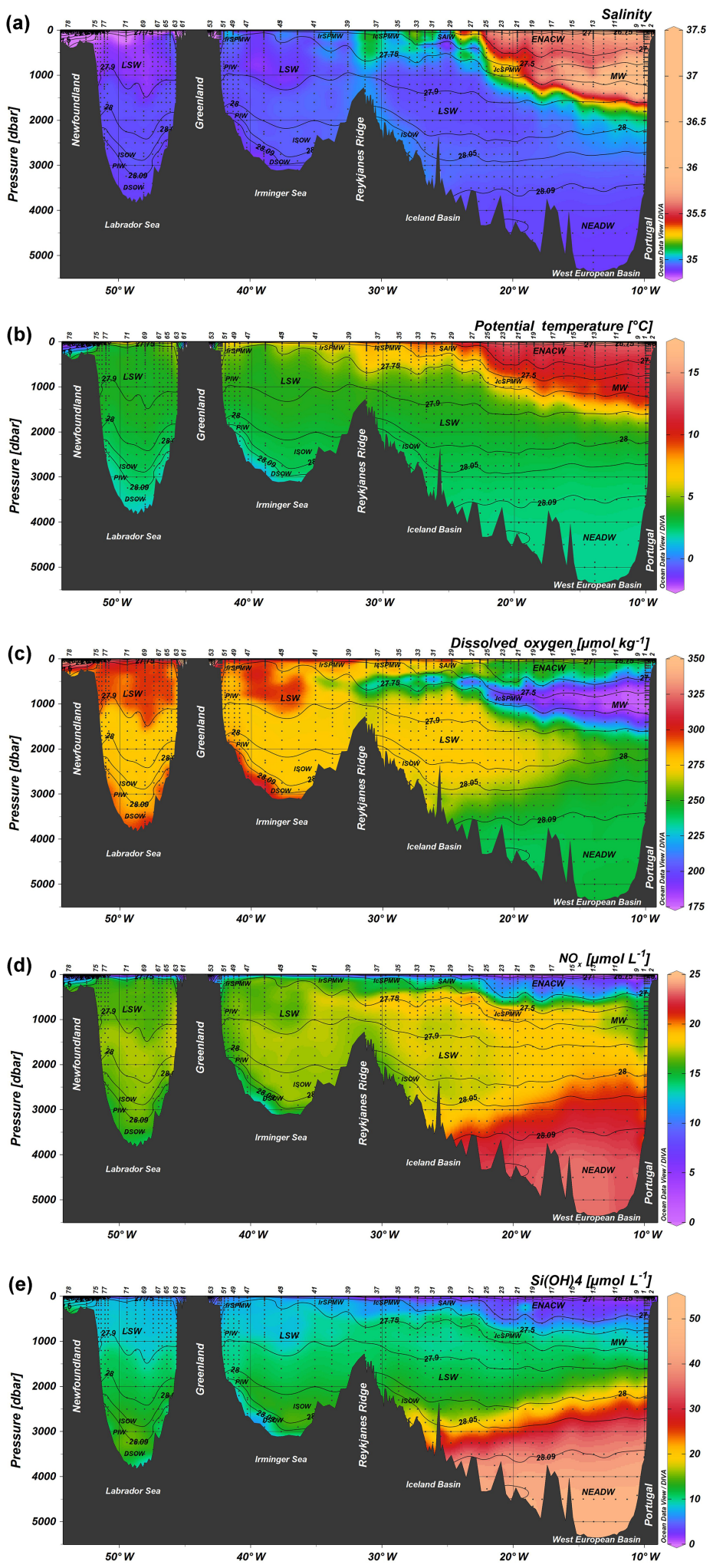

Figure 2. Section plots for (a) salinity, (b) potential temperature $\left({ }^{\circ} \mathrm{C}\right),(\mathbf{c})$ dissolved oxygen $\left(\mu \mathrm{mol} \mathrm{kg}{ }^{-1}\right),(\mathbf{d})$ nitrate + nitrite $\left(\mu \mathrm{mol} \mathrm{L}{ }^{-1}\right)$, and (e) silicic acid $\left(\mu \mathrm{mol} \mathrm{L}^{-1}\right)$ during the GEOVIDE cruise. Water masses are indicated in black, MW: Mediterranean Water; ENACW: North Atlantic Central Water; NEADW: North East Atlantic Deep Water; LSW: Labrador Sea Water; ISOW: Iceland-Scotland Overflow Water; SAIW: Subarctic Intermediate Water; IcSPMW: Iceland Subpolar Mode Water; IrSPMW: Irminger Subpolar Mode Water. Station locations are indicated by the numbers at the top of the panel. These plots were generated by Ocean Data View (Schlitzer, 2017). 
flow of both the Subpolar Mode Water of the Irminger Basin (SPMW, 200 to $1500 \mathrm{~m}$ ) and the Iceland-Scotland Overflow Water (ISOW, between 1800 and $3000 \mathrm{~m}$ ) in its lower limb (García-Ibáñez et al., 2018).

In addition, the precise determination of different water masses (García-Ibáñez et al., 2018) and ventilation processes is crucial for the interpretation of the TEIs whose distributions are, for many of them, strongly related to water masses.

\subsection{Links between water masses and TEIs}

The concentrations of TEIs are strongly influenced by water mass distribution, age, and circulation/mixing. For instance, for the case of ${ }^{230} \mathrm{Th}$ and ${ }^{231} \mathrm{~Pa}$, high concentrations of both tracers were observed in the old water of North East Atlantic Deep Water (NEADW), and low values in young waters, particularly in Denmark Strait Overflow Water (DSOW) (Deng et al., 2018). The low values of ${ }^{230} \mathrm{Th}$ and ${ }^{231} \mathrm{~Pa}$ in water near the seafloor of the Labrador and Irminger seas are related to the young waters present in those regions (Deng et al., 2018). This study reports a systematic increase of ${ }^{230} \mathrm{Th}$ activities with water age but a more complex relationship between age and ${ }^{231} \mathrm{~Pa}$, which challenges some approaches to the use of sedimentary ${ }^{231} \mathrm{~Pa} /{ }^{230} \mathrm{Th}$ ratios to assess past rates of oceanic circulation. The application of this proxy at a basin scale to constrain the overturning circulation is, however, supported by GEOVIDE data, which now allows a complete nuclide budget for the North Atlantic to be constructed (Deng et al., 2018).

Long-lived artificial radionuclides were also very useful to assess the circulation in the SPNA, namely ${ }^{129} \mathrm{I}$ and ${ }^{236} \mathrm{U}$, and the origin of water masses in a dual tracer approach (i.e. ${ }^{129} \mathrm{I} /{ }^{236} \mathrm{U}$ and ${ }^{236} \mathrm{U} /{ }^{238} \mathrm{U}$ atom ratios) (Castrillejo et al., 2018). These transient tracers, originating from La Hague (France) and Sellafield (UK) nuclear reprocessing plants and the atmospheric nuclear weapon tests, helped investigating the shallow western boundary transport and the ventilation processes. For example, the ${ }^{129}$ I concentrations validate the ISOW transport pathways in the West European Basin. The time series of ${ }^{129} \mathrm{I}$ in the Labrador Sea revealed two circulation loops of the Atlantic Waters carrying the signal from the European reprocessing plants: (i) a short loop through the Nordic seas into the central Labrador Sea of about 8 10 years; and (ii) a longer loop which includes about 8 additional years of recirculation in the Arctic Eurasian Basin before entering back into the Atlantic Ocean (Castrillejo et al., 2018).

Some other TEIs were also strongly linked to water mass distribution: within GEOVIDE, silicon isotopes (Sutton et al., 2018), lead (Pb) (Zurbrick et al., 2018), mercury ( $\mathrm{Hg}$ ) (Cossa et al., 2018a), and particulate and dissolved $\mathrm{Fe}$ and Al (Gourain et al., 2018; Menzel Barraqueta et al., 2018a; Tonnard et al., 2018), for example. For instance, the Labrador Sea Water (LSW) is characterized by a relatively high silicon stable isotope composition for dissolved silicon $\left(\delta^{30} \mathrm{Si}_{\mathrm{DSi}}\right)$ whose signature can be seen not only in the region where it is formed, but also throughout the mid-depth zone of the North Atlantic Ocean (Sutton et al., 2018). The $\delta^{30} \mathrm{Si}$ DSi distribution thus provides information on the interaction between subpolar-polar water masses of northern and southern origin, and indicates the extent to which local signatures are influenced by source waters (Sutton et al., 2018). In LSW, the concentrations of $\mathrm{Pb}$ (Zurbrick et al., 2018) and $\mathrm{Hg}$ (Cossa et al., 2018a) provided evidence for a decrease in the anthropogenic inputs of these two elements over the last decade, since the values are lower in the recently formed LSW between Greenland and Newfoundland than in the older LSW of the West European Basin.

The Mediterranean Water (MW), meanwhile, was characterized by higher concentrations of trace metals, such as $\mathrm{Pb}$, $\mathrm{Hg}$, and $\mathrm{Al}$ (Cossa et al., 2018a; Menzel Barraqueta et al., 2018a; Zurbrick et al., 2018). It reflects the importance of Saharan and anthropogenic atmospheric inputs to the Mediterranean region, which are much higher than in our studied area (see below), as well as enhanced remineralization as indicated by the correlation between total mercury concentrations and the apparent oxygen utilization (Cossa et al., 2018a).

\subsection{TEI sources and sinks}

Different methods and TEIs were used to estimate atmospheric input fluxes: aerosol concentrations in aerosol and rainwater samples were compared with estimates derived from the measurement of beryllium-7 $\left({ }^{7} \mathrm{Be}\right)$ in aerosols, rainwater, and seawater (Shelley et al., 2017). Taking a different approach, Menzel Barraqueta et al. (2018b) used dAl in the surface waters to estimate the atmospheric input flux. All these methods allowed conclusion that the atmospheric inputs of total trace elements were low in our study area, and the soluble input was even lower, based on their fractional solubility (Shelley et al., 2018).

One of the main sources of TEIs during GEOVIDE was sediment input (i) within the benthic nepheloid layers in the Iceland, Irminger and Labrador basins (Gourain et al., 2018), and (ii) above the Iberian, Greenland and Canadian margins, as well as fluvial and meteoric inputs (Benetti et al., 2017). This is notably the case for some dissolved TEIs, such as Fe (Tonnard et al., 2018), Al (Menzel Barraqueta et al., $2018 \mathrm{a})$, and radium-226 $\left({ }^{226} \mathrm{Ra}\right)$ or barium (Ba) (Le Roy et al., 2018), as well as for particulate trace elements (Gourain et al., 2018). Overall, enhanced concentrations of TEIs close to the bottom suggest that continental shelves and margins acted as a source to adjacent waters. In the case of the Iberian margin, advection of particulate $\mathrm{Fe}(\mathrm{pFe})$ was visible over a distance of more than $250 \mathrm{~km}$ from the source (Gourain et al., 2018).

However, some results provide evidence that occasional removal of $\mathrm{dFe}$ or $\mathrm{dAl}$ by particles can be a dominant process rather than partial dissolution from resuspended sediments, 


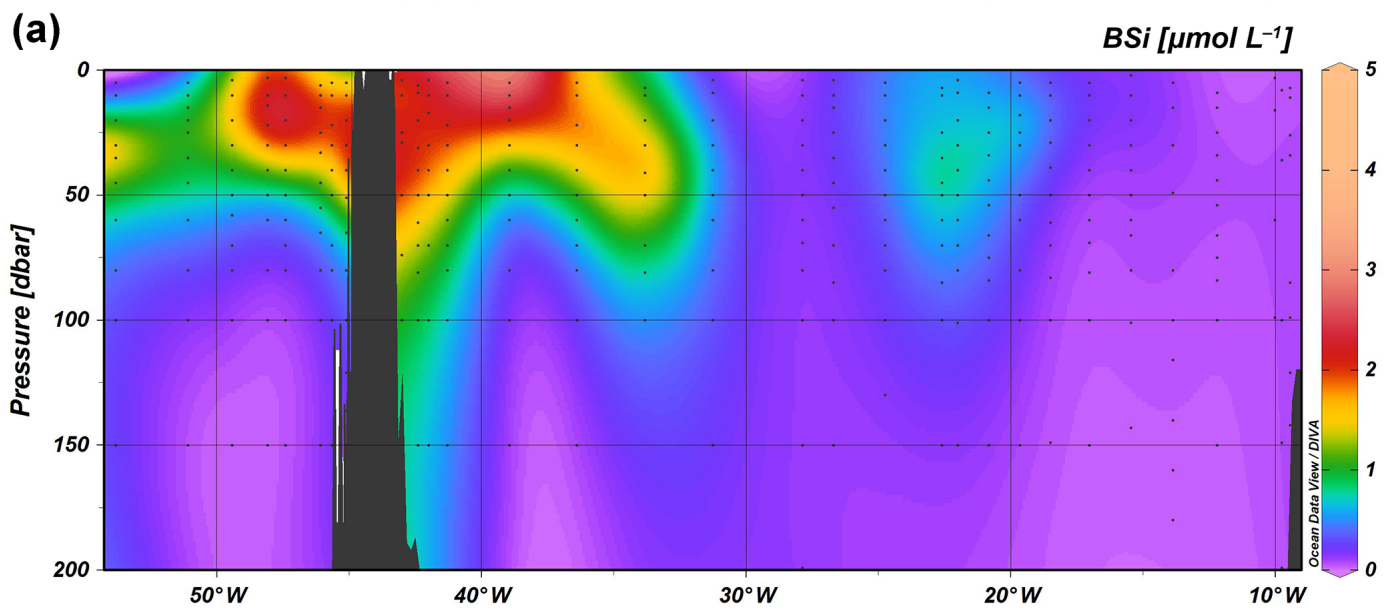

(b)
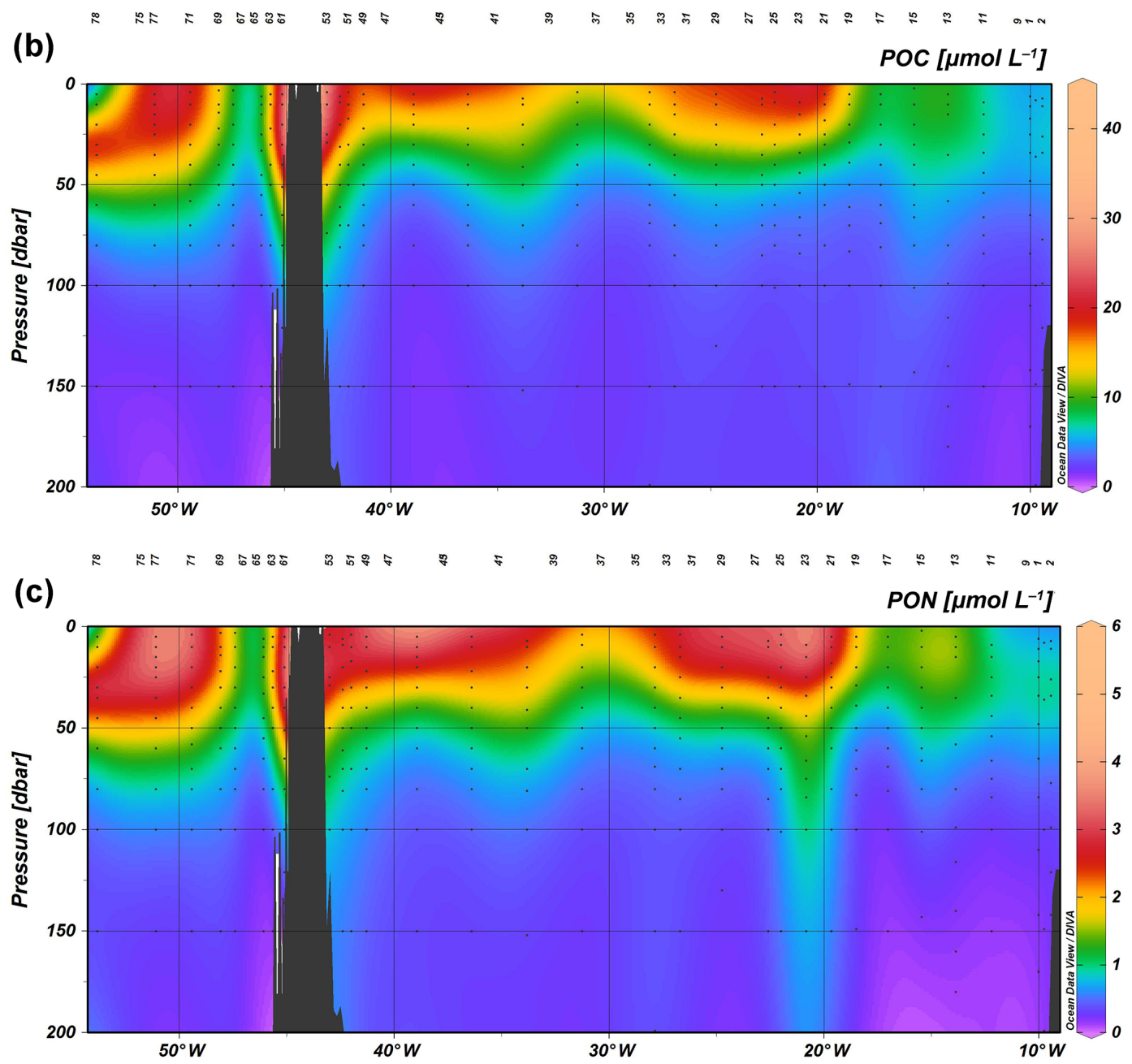

Figure 3. Section plots for (a) biogenic silica $(\mathrm{BSi}, \mu \mathrm{mol} \mathrm{L}-1)$, (b) particulate organic carbon (POC, $\mu \mathrm{mol} \mathrm{L}{ }^{-1}$ ), and (c) particulate organic nitrogen (PON, $\mu \mathrm{mol} \mathrm{L}^{-1}$ ), during the GEOVIDE cruise. Station locations are indicated by the numbers at the top of the panel. These plots were generated by Ocean Data View (Schlitzer, 2017). 
but this is likely dependent on the nature of particles (Menzel Barraqueta et al., 2018a).

Additional sources for particulate elements and sinks for dissolved ones are biological uptake and scavenging. Evidence of a biogenic influence on the $\mathrm{pFe} / \mathrm{pAl}$ ratios within the Irminger and Labrador basins was found by Gourain et al. (2018). Almost all the stations displayed dFe minima in surface waters, in association with the chlorophyll maxima. The abundance of diatoms exerted a significant control on the surface concentrations of Fe and Al (Menzel Barraqueta et al., 2018b; Tonnard et al., 2018). Remineralization processes were also highlighted for some TEIs (see also Sect. 3.4). Dissolved Al concentrations generally increased with depth and the net release of $\mathrm{dAl}$ at depth during remineralization of sinking biogenic opal containing particles was generally larger than the net removal of $\mathrm{dAl}$ through scavenging.

\subsection{Production, export, and remineralization}

The main biogeochemical features of the GEOVIDE cruise in terms of biogenic silica (BSi), particulate organic carbon (POC), and particulate organic nitrogen (PON) are reported in Fig. 3 and the Supplement. The highest BSi concentrations were observed in the Irminger and Labrador seas. POC and PON were also high in these regions, but also show high values in the Iceland and West European basins.

On the Iberian margin and in the West European Basin, an unexpectedly high heterotrophic nitrogen fixation activity was reported, likely sustained by the availability of phytoplankton-derived organic matter (dissolved and/or particulate), resulting from the ongoing to post-spring bloom conditions, while dissolved iron supply relied on atmospheric deposition and surface waters' advection from the subtropical region and the shelf area (Fonseca-Batista et al., 2018).

In terms of particulate organic carbon (POC) export, thorium-234 $\left({ }^{234} \mathrm{Th}\right)$ was used to provide estimates of POC export fluxes, with the highest values near the Iberian margin where a phytoplankton bloom was declining, and the lowest values in the Irminger Basin where the bloom was close to its maximum (Lemaitre et al., 2018a). The proxy ${ }^{210} \mathrm{Po} /{ }^{210} \mathrm{~Pb}$ was also used to assess the export of particles (Tang et al., 2018). The prominent role of small particles in sorption was confirmed, suggesting that particulate radionuclide activities and export of both small $(1-53 \mu \mathrm{m})$ and large $(>53 \mu \mathrm{m})$ particles should be considered to account for the observed surface water ${ }^{210} \mathrm{Po} /{ }^{210} \mathrm{~Pb}$ disequilibria (Tang et al., 2018).

In the subpolar and subtropical regions, the mesopelagic POC remineralization fluxes, estimated from the particulate biogenic barium (excess barium; $\mathrm{Ba}_{\mathrm{xs}}$ ) proxy, were found to be equal to and occasionally higher than the upper ocean POC export fluxes (Lemaitre et al., 2018b). These results highlighted the strong impact of the mesopelagic remineralization on the biological carbon pump with a very low carbon sequestration efficiency at the time of our study (Lemaitre et al., 2018b).

\section{Conclusions}

The main GEOVIDE results have helped to improve our understanding of the TEI cycles in the North Atlantic. The strong physical oceanography background of the GEOVIDE project is a strength for interpreting our data. For many TEIs, a strong link was observed between their distributions and water masses. On the other hand, TEIs also helped to constrain oceanic circulation, notably in the subpolar gyre and Labrador Sea. Important sources (sediments, fluvial, and meteoric) and sinks (biological uptake and scavenging) of TEIs were highlighted. The biological carbon pump was studied and showed different efficiencies in the various studied regions.

Data availability. Data are available in the SEANOE database at https://doi.org/10.17882/54653 (Perez et al., 2018) and the LEFE CYBER database at http://www.obs-vlfr.fr/proof/php/geovide/x_ datalist_1.php?xxop=geovide\&xxcamp=geovide (Schmechtig et al., 2018), and on request from the lead author.

Supplement. The supplement related to this article is available online at: https://doi.org/10.5194/bg-15-7097-2018-supplement.

Author contributions. GS and PL were PIs of the GEOVIDE project and the chief scientists of the GEOVIDE cruise. They wrote the article and prepared all figures, with contributions from all coauthors.

Competing interests. The authors declare that they have no conflict of interest.

Special issue statement. This article is part of the special issue "GEOVIDE, an international GEOTRACES study along the OVIDE section in the North Atlantic and in the Labrador Sea (GA01)". It is not associated with a conference.

Acknowledgements. We are greatly thankful to the captain, Gilles Ferrand, and crew of the N/O Pourquoi Pas? for their help during the GEOVIDE mission. This work was supported by the French National Research Agency (ANR-13-BS06-0014, ANR12-PDOC-0025-01), the French National Centre for Scientific Research (CNRS-LEFE-CYBER), the LabexMER (ANR-10LABX-19), and Ifremer. Logistics were supported by DT-INSU and GENAVIR.

Edited by: Laurent Bopp

Reviewed by: two anonymous referees 


\section{References}

Baker, A. R., Landing, W. F., Bucciarelli, E., Cheize, M., Fietz, S., Hayes, C. T., Kadko, D., Morton, P. L., Rogan, N., Sarthou, G., Shelley, R. U., Shi, Z., Shiller, A. M., and Van Hulten, M. M. P.: Air - Sea Deposition of Trace Elements - Philosophical Transactions of the Royal Society of London A: Mathematical, Physical and Engineering Sciences, available at: http://rsta. royalsocietypublishing.org/content/374/2081/20160190 (last access: 18 June 2018), 2016.

Benetti, M., Reverdin, G., Lique, C., Yashayaev, I., Holliday, N. P., Tynan, E., Torres-Valdes, S., Lherminier, P., Tréguer, P., and Sarthou, G.: Composition of freshwater in the spring of 2014 on the southern Labrador shelf and slope, J. Geophys. Res.-Oceans, 122, 1102-1121, https://doi.org/10.1002/2016JC012244, 2017.

Blain, S., Quéguiner, B., Armand, L., Belviso, S., Bombled, B., Bopp, L., Bowie, A., Brunet, C., Brussaard, C., Carlotti, F., Christaki, U., Corbière, A., Durand, I., Ebersbach, F., Fuda, J.L., Garcia, N., Gerringa, L., Griffiths, B., Guigue, C., Guillerm, C., Jacquet, S., Jeandel, C., Laan, P., Lefèvre, D., Lomonaco, C., Malits, A., Mosseri, J., Obernosterer, I., Park, Y.-H., Picheral, M., Pondaven, P., Remenyi, T., Sandroni, V., Sarthou, G., Savoye, N., Scouarnec, L., Souhaut, M., Thuiller, D., Timmermans, K., Trull, T., Uitz, J., van-Beek, P., Veldhuis, M., Vincent, D., Viollier, E., Vong, L., and Wagener, T.: Impact of natural iron fertilization on carbon sequestration in the Southern Ocean, Nature, 7139, 10701074, 2007.

Boyd, P. W., Jickells, T., Law, C. S., Blain, S., Boyle, E. A., Buesseler, K. O., Coale, K. H., Cullen, J. J., Baar, H. J. W. de, Follows, M., Harvey, M., Lancelot, C., Levasseur, M., Owens, N. P. J., Pollard, R., Rivkin, R. B., Sarmiento, J., Schoemann, V., Smetacek, V., Takeda, S., Tsuda, A., Turner, S., and Watson, A. J.: Mesoscale Iron Enrichment Experiments 1993-2005: Synthesis and Future Directions, Science, 315, 612-617, 2007.

Buesseler, K. O., Andrews, J. E., Pike, S. M., and Charette, M. A.: The effects of iron fertilization on carbon sequestration in the Southern Ocean, Science, 304, 414-417, 2004.

Bury, S. J., Boyd, P. W., Preston, T., Savidge, G., and Owens, N. J. P.: Size-fractionated primary production and nitrogen uptake during a North Atlantic phytoplankton bloom?: implications for carbon export estimates, Deep-Sea Res. Pt. 1, 48, 689-720, 2001.

Casacuberta, N., Masqué, P., Henderson, G., Rutgers van-derLoeff, M., Bauch, D., Vockenhuber, C., Daraoui, A., Walther, C., Synal, H.-A., and Christl, M.: First 236U data from the Arctic Ocean and use of $236 \mathrm{U} / 238 \mathrm{U}$ and 129I/236U as a new dual tracer, Earth Planet. Sc. Lett., 440, 127-134, https://doi.org/10.1016/j.epsl.2016.02.020, 2016.

Castrillejo, M., Casacuberta, N., Christl, M., Vockenhuber, C., Synal, H.-A., García-Ibáñez, M. I., Lherminier, P., Sarthou, G., Garcia-Orellana, J., and Masqué, P.: Tracing water masses with ${ }^{129} \mathrm{I}$ and ${ }^{236} \mathrm{U}$ in the subpolar North Atlantic along the GEOTRACES GA01 section, Biogeosciences, 15, 5545-5564, https://doi.org/10.5194/bg-15-5545-2018, 2018.

Chase, Z., Johnson, K. S., Elrod, V. A., Plant, J. N., Fitzwater, S. E., Pickella, L., and Sakamotob, C. M.: Manganese and iron distributions off central California influenced by upwelling and shelf width, Mar. Chem., 95, 235-254, 2005.

Copard, K., Colin, C., Frank, N., Jeandel, C., Montero-Serrano, J. C., Reverdin, G,. and Ferron, B.: Nd isotopic composition of water masses and dilution of the Mediterranean outflow along the southwest European margin, Geochem. Geophy. Geosy., 12, Q06020, https://doi.org/10.1029/2011GC003529, 2011.

Cossa, D., Heimbürger, L.-E., Pérez, F. F., García-Ibáñez, M. I., Sonke, J. E., Planquette, H., Lherminier, P., Boutorh, J., Cheize, M., Menzel Barraqueta, J. L., Shelley, R., and Sarthou, G.: Mercury distribution and transport in the North Atlantic Ocean along the GEOTRACES-GA01 transect, Biogeosciences, 15, 23092323, https://doi.org/10.5194/bg-15-2309-2018, 2018 a.

Cossa, D., Heimbürger, L. E., Sonke, J. E., Planquette, H., Lherminier, P., García-Ibáñez, M. I., Pérez, F. F., and Sarthou, G.: Sources, cycling and transfer of mercury in the Labrador Sea (Geotraces-Geovide cruise), Mar. Chem., 198, 64-69, https://doi.org/10.1016/j.marchem.2017.11.006, 2018b.

Daniault, N., Mercier, H., Lherminier, P., Sarafanov, A., Falina, A., Zunino, P., Pérez, F. F., Ríos, A. F., Ferron, B., Huck, T., Thierry, V., and Gladyshev, S.: The northern North Atlantic Ocean mean circulation in the early 21 st century, Prog. Oceanogr., 146, 142 158, https://doi.org/10.1016/j.pocean.2016.06.007, 2016.

de Baar, H. J. W., Boyd, P. X., Coale, K. H., Landry, M. R., Tsuda, A., Assmy, P., Bakker, D. C. E., Bozec, Y., Barber, R. T., Brzezinski, M. A., Buesseler, K. O., Boye, M., Croot, P. L., Gervais, F., Gorbunov, M. Y., Harrison, P. J., Hiscock, W. T., Laan, P., Lancelot, C., Law, C. S., Levasseur, M., Marchetti, A., Millero, F., Nishioka, J., Nojiri, Y., van Oijen, T., Riebesell, U., Rijkenberg, M. J. A., Saito, H., Takeda, S., Timmermans, K. R., Veldhuis, M. J. W., Waite, A. M., and Wong, C.-S.: Synthesis of iron fertilization experiments: From the Iron Age in the Age of Enlightenment, J. Geophys. Res., 110, C09S16, https://doi.org/10.1029/2004JC002601, 2005.

De La Rocha, C. L., Hutchins, D. A., Brzezinski, M. A., and Zhang, Y.: Effects of iron and zinc deficiency on elemental composition and silica production by diatoms, Mar. Ecol. Prog. Ser., 195, 7179, 2000

De La Rocha, C. L., Bescont, P., Croguennoc, A., and Ponzevera, E.: The silicon isotopic composition of surface waters of the Atlantic and Indian sectors of the Southern Ocean, Geochim. Cosmochim. Ac., 75, 5283-5295, 2011.

de Leeuw, G., Guieu, C., Arneth, A., Bellouin, N., Bopp, L., Boyd, P. W., Denier van der Gon, H. A. C., Desboeufs, K. V., Dulac, F., Facchini, M. C., Gantt, B., Langmann, B., Mahowald, N. M., Marañon, E., O’Dowd, C., Olgun, N., Pulido-Villena, E., Rinaldi, M., Stephanou, E. G., and Wagener, T.: Ocean-atmosphere interactions of particles, in Ocean-Atmosphere Interactions of Gases and Particles, edited by: Johnson, M. T., 171-246, https://doi.org/10.1007/978-3-642-25643-1_4, Springer, Heidelberg, 2014.

Dehairs, F., Shopova, D., Ober, S., Veth, C., and Goeyens, L.: Particulate barium stocks and oxygen consumption in the Southern Ocean mesopelagic water column during spring and early summer: relationship with export production, Deep-Sea Res. Pt. II, 44, 497-516, https://doi.org/10.1016/S0967-0645(96)00072$0,1997$.

Deng, F., Henderson, G. M., Castrillejo, M., and Perez, F. F.: Evolution of ${ }^{231} \mathrm{~Pa}$ and ${ }^{230} \mathrm{Th}$ in overflow waters of the North Atlantic, Biogeosciences Discuss., https://doi.org/10.5194/bg-2018-191, in review, 2018.

Duce, R. A., LaRoche, J., Altieri, K., Arrigo, K. R., Baker, A. R., Capone, D. G., Cornell, S., Dentener, F., Galloway, J., Ganeshram, R. S., Geider, R. J., Jickells, T., Kuypers, M. M., 
Langlois, R., Liss, P. S., Liu, S. M., Middelburg, J. J., Moore, C. M., Nickovic, S., Oschlies, A., Pedersen, T., Prospero, J., Schlitzer, R., Seitzinger, S., Sorensen, L. L., Uematsu, M., Ulloa, O., Voss, M., Ward, B., and Zamora, L.: Impacts of atmospheric anthropogenic nitrogen on the open ocean, Science, 320, 893-897, https://doi.org/10.1126/science.1150369, 2008.

Filippova, A., Frank, M., Kienast, M., Rickli, J., Hathorne, E., Yashayaev, I. M., and Pahnke, K.: Water mass circulation and weathering inputs in the Labrador Sea based on coupled $\mathrm{Hf}-\mathrm{Nd}$ isotope compositions and rare earth element distributions, Geochim. Cosmochim. Ac., 199, 164-184, https://doi.org/10.1016/j.gca.2016.11.024, 2017.

Fischer, J., Visbeck, M., Zantopp, R., and Nunes, N.: Interannual to decadal variability of outflow from the Labrador Sea, Geophys. Res. Lett., 37, L24610, https://doi.org/10.1029/2010GL045321, 2010.

Fonseca-Batista, D., Li, X., Riou, V., Michotey, V., Deman, F., Fripiat, F., Guasco, S., Brion, N., Lemaitre, N., Tonnard, M., Gallinari, M., Planquette, H., Planchon, F., Sarthou, G., Elskens, M., Chou, L., and Dehairs, F.: Evidence of high $\mathrm{N}_{2}$ fixation rates in productive waters of the temperate Northeast Atlantic, Biogeosciences Discuss., https://doi.org/10.5194/bg-2018-220, in review, 2018.

Fripiat, F., Cavagna, A.-J., Nicolas, S., Dehairs, F., Andre, L., and Cardinal, D.: Isotopic constraints on the Si-biogeochemical cycle of the Antarctic Zone in the Kerguelen area (KEOPS), Mar. Chem., 123, 11-22, https://doi.org/10.1016/j.marchem.2010.08.005, 2011.

Fröb, F., Olsen, A., Pérez, F. F., García-Ibáñez, M. I., Jeansson, E., Omar, A., and Lauvset, S. K.: Inorganic carbon and water masses in the Irminger Sea since 1991, Biogeosciences, 15, 5172, https://doi.org/10.5194/bg-15-51-2018, 2018.

García-Ibáñez, M. I., Pérez, F. F., Lherminier, P., Zunino, P., Mercier, H., and Tréguer, P.: Water mass distributions and transports for the 2014 GEOVIDE cruise in the North Atlantic, Biogeosciences, 15, 2075-2090, https://doi.org/10.5194/bg-152075-2018, 2018.

Gourain, A., Planquette, H., Cheize, M., Lemaitre, N., Menzel Barraqueta, J.-L., Shelley, R., Lherminier, P., and Sarthou, G.: Inputs and processes affecting the distribution of particulate iron in the North Atlantic along the GEOVIDE (GEOTRACES GA01) section, Biogeosciences Discuss., https://doi.org/10.5194/bg-2018234, in review, 2018

Hayes, C. T., Anderson, R. F., Fleisher, M. Q., Huang, K.-F., Robinson, L. F., Lu, Y., Cheng, H., Edwards, R. L., and Moran, S. B.: 230Th and 231Pa on GEOTRACES GA03, the U.S. GEOTRACES North Atlantic transect, and implications for modern and paleoceanographic chemical fluxes, Deep-Sea Res. Pt. II, 116, 29-41, https://doi.org/10.1016/j.dsr2.2014.07.007, 2015.

Henderson, G. M.: New oceanic proxies for paleoclimate, Earth Planet. Sc. Lett., 203, 1-13, 2002.

Henson, S. A., Dunne, J. P., and Sarmiento, J. L.: Decadal variability in North Atlantic phytoplankton blooms, J. Geophys. Res., 114, C04013, https://doi.org/10.1029/2008JC005139, 2009.

Holliday, N. P., Bacon, S., Cunningham, S. A., Gary, S. F., Karstensen, J., King, B. A., Li, F., and Mcdonagh, E. L.: Subpolar North Atlantic Overturning and Gyre-Scale Circulation in the Summers of 2014 and 2016, J. Geophys. Res.-Oceans, 123, 4538-4559, https://doi.org/10.1029/2018JC013841, 2018.
Hsieh, Y.-T., Henderson, G. M., and Thomas, A. L.: Combining seawater $232 \mathrm{Th}$ and $230 \mathrm{Th}$ concentrations to determine dust fluxes to the surface ocean, Earth Planet. Sc. Lett., 312, 280-290, https://doi.org/10.1016/j.epsl.2011.10.022, 2011.

Jeandel, C. and Oelkers, E. H.: The influence of terrigenous particulate material dissolution on ocean chemistry and global element cycles, Chem. Geol., 395, 50-66, https://doi.org/10.1016/j.chemgeo.2014.12.001, 2015.

Jeandel, C., Peucker Ehrenbrink, B., Jones, M., Pearce, C., Oelkers, E., Godderis, Y., Lacan, F., Aumont, O., and Arsouze, T.: Ocean margins: the missing term for oceanic element budgets?, EOS, 92, 217-219, 2011.

Jickells, T. D., An, Z. S., Andersen, K. K., Baker, A. R., Bergametti, G., Brooks, N., Cao, J. J., Boyd, P. W., Duce, R. A., Hunter, K. A., Kawahata, H., Kubilay, N., La Roche, J., Liss, P. S., Mahowald, N., Prospero, J. M., Ridgwell, A. J., Tegen, I., and Torres, R.: Global Iron Connections Between Desert Dust, Ocean Biogeochemistry, and Climate, Science, 308, 67-71, 2005.

Kanzow, T., Cunningham, S. A., Johns, W. E., Hirschi, J. J.M., Marotzke, J., Baringer, M. O., Meinen, C. S., Chidichimo, M. P., Atkinson, C., Beal, L. M., Bryden, H. L., and Collins, J.: Seasonal Variability of the Atlantic Meridional Overturning Circulation at $26.5^{\circ} \mathrm{N}$, J. Climate, 23, 5678-5698, https://doi.org/10.1175/2010JCLI3389.1, 2010.

Keigwin, L. D. and Boyle, E. A.: Did North Atlantic overturning halt 17,000 years ago?, Paleoceanography, 23, PA1101, https://doi.org/10.1029/2007PA001500, 2008.

Key, R. M., Kozyr, A., Sabine, C. L., Lee, K., Wanninkhof, R., Bullister, J. L., Feely, R. A., Millero, F. J., Mordy, C., and Peng, T.-H.: A global ocean carbon climatology: Results from the Global Data Analysis Project (GLODAP), Global Biogeochem. Cy., 18, GB4031, https://doi.org/10.1029/2004GB002247, 2004.

Lacan, F. and Jeandel, C.: Traging Papua New Guinea imprint on the central Equatorial Pacific Ocean using neodynium isotopic compositions and Rare Earth Element patterns, Earth Planet. Sc. Lett., 5779, 1-16, 2001.

Lacan, F. and Jeandel, C.: Subpolar Mode Water formation traced by neodymium isotopic composition, Geophys. Res. Lett., 31, L14306, https://doi.org/10.1029/2004GL019747, 2004, 2004.

Lacan, F. and Jeandel, C.: Neodymium isotopes as a new tool for quantifying exchange fluxes at the continentocean interface, Earth Planet. Sc. Lett., 232, 245-257, https://doi.org/10.1016/j.eps1.2005.01.004, 2005.

Lambelet, M., van de Flierdt, T., Crocket, K., Rehkämper, M., Kreissig, K., Coles, B., Rijkenberg, M. J. A., Gerringa, L. J. A., de Baar, H. J. W., and Steinfeldt, R.: Neodymium isotopic composition and concentration in the western North Atlantic Ocean: Results from the GEOTRACES GA02 section, Geochim. Cosmochim. Act., 177, 1-29, https://doi.org/10.1016/j.gca.2015.12.019, 2016.

Lampitt, R. S.: Evidence for the seasonal deposition of detritus to the deep-sea floor and its subsequent resuspension, Deep-Sea Res Pt. I, 32, 885-897, 1985.

Le Reste, S., Dutreuil, V., André, X., Thierry, V., Renaut, C., Le Traon, P.-Y., and Maze, G.: "Deep-Arvor": A New Profiling Float to Extend the Argo Observations Down to 4000-m Depth, J. Atmos. Ocean. Tech., 33, 1039-1055, https://doi.org/10.1175/JTECH-D-15-0214.1, 2016. 
Le Roy, E., Sanial, V., Charette, M. A., van Beek, P., Lacan, F., Jacquet, S. H. M., Henderson, P. B., Souhaut, M., García-Ibáñez, M. I., Jeandel, C., Pérez, F. F., and Sarthou, G.: The ${ }^{226} \mathrm{Ra}-\mathrm{Ba}$ relationship in the North Atlantic during GEOTRACES-GA01, Biogeosciences, 15, 3027-3048, https://doi.org/10.5194/bg-153027-2018, 2018.

Lemaitre, N., Planchon, F., Planquette, H., Dehairs, F., FonsecaBatista, D., Roukaerts, A., Deman, F., Tang, Y., Mariez, C., and Sarthou, G.: High variability of particulate organic carbon export along the North Atlantic GEOTRACES section GA01 as deduced from ${ }^{234} \mathrm{Th}$ fluxes, Biogeosciences, 15, 6417-6437, https://doi.org/10.5194/bg-15-6417-2018, 2018a.

Lemaitre, N., Planquette, H., Planchon, F., Sarthou, G., Jacquet, S., García-Ibáñez, M. I., Gourain, A., Cheize, M., Monin, L., André, L., Laha, P., Terryn, H., and Dehairs, F.: Particulate barium tracing of significant mesopelagic carbon remineralisation in the North Atlantic, Biogeosciences, 15, 2289-2307, https://doi.org/10.5194/bg-15-2289-2018, 2018. 2018 b.

Lherminier, P., Mercier, H., Huck, T., Gourcuff, C., Perez, F. F., Morin, P., and Sarafanov, A.: The Atlantic meridional overturning circulation and the subpolar gyre observed at the A25-Ovide section in June 2002 and 2004, Deep-Sea Res. Pt. I, 57, 1374 1391, https://doi.org/10.1016/j.dsr.2010.07.009, 2010.

Mahowald, N. M., Baker, A. R., Bergametti, G., Brooks, N., Duce, R. A., Jickells, T. D., Kubilay, N., Prospero, J. M., and Tegen, I.: Atmospheric global dust cycle and iron inputs to the ocean, Global Biogeochem. Cy., 19, GB4025, https://doi.org/10.1029/2004GB002402, 2005.

McManus, J. F., Francois, R., Gherardi, J.-M., Keigwin, L. D., and Brown-Leger, S.: Collapse and rapid resumption of Atlantic meridional circulation linked to deglacial climate changes, Nature, 428, 834-837, 2004.

Measures, C. I. and Brown, E. T.: Estimating dust input to the Atlantic Ocean using surface water $\mathrm{Al}$ concentrations, in: The impact of African Dust across the Mediterranean, edited by: Guerzoni, S. and Chester, R., p. 389, Kluwer, 1996.

Menzel Barraqueta, J.-L., Schlosser, C., Planquette, H., Gourain, A., Cheize, M., Boutorh, J., Shelley, R., Contreira Pereira, L., Gledhill, M., Hopwood, M. J., Lacan, F., Lherminier, P., Sarthou, G., and Achterberg, E. P.: Aluminium in the North Atlantic Ocean and the Labrador Sea (GEOTRACES GA01 section): roles of continental inputs and biogenic particle removal, Biogeosciences, 15, 5271-5286, https://doi.org/10.5194/bg-155271-2018, 2018a.

Menzel Barraqueta, J.-L., Klar, J. K., Gledhill, M., Schlosser, C., Shelley, R., Planquette, H., Wenzel, B., Sarthou, G., and Achterberg, E. P.: Atmospheric aerosol deposition fluxes over the Atlantic Ocean: A GEOTRACES case study, Biogeosciences Discuss., https://doi.org/10.5194/bg-2018-209, in review, 2018b.

Mercier, H., Lherminier, P., Sarafanov, A., Gaillard, F., Daniault, N., Desbruyères, D., Falina, A., Ferron, B., Gourcuff, C., Huck, T., and Thierry, V.: Variability of the Meridional Overturning Circulation at the Greenland-Portugal Ovide section from 1993 to 2010, Prog. Oceanogr., 132, 250-261, https://doi.org/10.1016/j.pocean.2013.11.001, 2015.

Montero-Serrano, J. C., Frank, N., Tisnérat-Laborde, N., Colin, C., Wu, C. C., Lin, K., Shen, C. C., Copard, K., Orejas, C., Gori, A., De Mol, L., Van Rooij, D., Reverdin, G., and Douville, E.: Decadal changes in the mid-depth water mass dynamic of the
Northeastern Atlantic margin (Bay of Biscay), Earth Planet. Sc. Lett., 364, 134-144, 2013.

Moran, S. B., Shen, C.-C., Edmonds, H. N., Weinstein, S. E., Smith, J. N., and Edwards, R. L.: Dissolved and particulate $231 \mathrm{~Pa}$ and $230 \mathrm{Th}$ in the Atlantic Ocean: constraints on intermediate/deep water age, boundary scavenging, and 231Pa/230Th fractionation, Earth Planet. Sc. Lett., 203, 999 1014, https://doi.org/10.1016/S0012-821X(02)00928-7, 2002.

Negre, C., Zahn, R., Thomas, A. L., Masque, P., Henderson, G. M., Martinez-Mendez, G., Hall, I. R., and Mas, J. L.: Reversed flow of Atlantic deep water during the Last Glacial Maximum, Nature, 468, 84-88, 2010.

Perez, F., Treguer, P., Branellec, P., García-Ibáñez, M. I., Lherminier, P., and Sarthou, G.: The 2014 Greenland-Portugal GEOVIDE bottle data (GO-SHIP A25 and GEOTRACES GA01), https://doi.org/10.17882/54653, 2018.

Pérez, F. F., Mercier, H., Vázquez-Rodríguez, M., Lherminier, P., Velo, A., Pardo, P. C., Rosón, G., and Ríos, A. F.: Atlantic Ocean $\mathrm{CO} 2$ uptake reduced by weakening of the meridional overturning circulation, Nat. Biogeosci., 6, 146-152, https://doi.org/10.1038/NGEO1680, 2013.

Pérez, F. F., Fontela, M., García-Ibáñez, M. I., Mercier, H., Velo, A., Lherminier, P., Zunino, P., Paz, M. de la, Alonso-Pérez, F., Guallart, E. F., and Padin, X. A.: Meridional overturning circulation conveys fast acidification to the deep Atlantic Ocean, Nature, 554, 515-518, https://doi.org/10.1038/nature25493, 2018.

Pollard, R., Sanders, R., Lucasa, M., and Statham, P.: The Crozet Natural Iron Bloom and Export Experiment (CROZEX), DeepSea Res. Pt. II, 54, 1905-1914, 2007.

Reverdin, G., Cayan, D., Dooley, H. D., Ellett, D. J., Levitus, S., Du Penhoat, Y., and Dessier, A.: Surface salinity of the North Atlantic: Can we reconstruc its fluctuations over the last one hundred years?, Prog. Oceanogr., 33, 303-346, 1994.

Roca-Martí, M., Puigcorbé, V., Loeff, M. M. R. van der, Katlein, C., Fernández-Méndez, M., Peeken, I., and Masqué, P.: Carbon export fluxes and export efficiency in the central Arctic during the record sea-ice minimum in 2012: a joint $234 \mathrm{Th} / 238 \mathrm{U}$ and 210Po/210Pb study, J. Geophys. Res.-Oceans, 121, 5030-5049, https://doi.org/10.1002/2016JC011816, 2016.

Sabine, C. L., Feely, R. A., Gruber, N., Key, R. M., Lee, K., Bullister, J. L., Wanninkhof, R., Wong, C. S., Wallace, D. W. R., Tilbrook, B., Millero, F. J., Peng, T.-H., Kozyr, A., Ono, T., and Rios, A. F.: The oceanic sink for anthropogenic CO2, Science, 682, 367-371, 2004.

Savidge, G., Boyd, P., Pomroy, A., Harbour, D., and Joint, I.: Phytoplankton production and biomass estimates in the Northeast Atlantic Ocean, May-June 1990, Deep-Sea Res. Pt. I, 42, 599-617, 1995.

Schlitzer, R.: Ocean Data View, available at: https://odv.awi.de, last access: 24 November 2017.

Schmechtig, C., Sarthou, G., Lherminier, P., Achterberg, E. P., Alonso-Pérez, F., Bucciarelli, E., Boutorh, J., Bouvier, V., Boyle, E. A., Branellec, P., Carracedo, L. I., Casacuberta, N. Castrillejo, M., Cheize, M., Contreira Pereira, L., Cossa, D., Daniault, N., De Saint-Léger, Dehairs, E. F., Deng, F., Desprez de Gésincourt, F., Devesa, J., Foliot, L., Fonseca-Batista, D., Gallinari, M., García-Ibáñez, M. I., Gourain, A., Grossteffan, E., Hamon, M., Heimbürger, L. E., Henderson, G. M., Jeandel, C., Kermabon, C., Lacan, F., Le Bot, P., Le Goff, M., Le Roy, E., 
Lefèbvre, A., Leizour, S., Lemaitre, N., Masqué, P., Ménage, O., Menzel Barraqueta, J.-L., Mercier, H., Perault, F., Pérez, F. F., Planquette, H. F., Planchon, F., Roukaerts, A., Sanial, V., Sauzède, R., Shelley, R. U., Stewart, G., Sutton, J. N., Tang, Y., Tisnérat-Laborde, N., Tonnard, M., Tréguer, P., van Beek, P., Zurbrick, C. M., and Zunino, P.: Oceanographic dataset in the North Atlantic Sea collected during the cruise GEOVIDE 2014, available at: http://www.obs-vlfr.fr/proof/php/geovide/x datalist_1.php?xxop=geovide $\&$ xxcamp=geovide, last access: 26 November 2018.

Seager, R., Battisti, D. S., Yin, J., Gordon, N., Naik, N., Clement, A. C., and Cane, M. A.: Is the Gulf Stream responsible for Europe's mild winters?, Q. J. Roy. Meteor. Soc., 128, 2563-2586, 2002.

Shelley, R. U., Roca-Martí, M., Castrillejo, M., Sanial, V., Masqué, P., Landing, W. M., van Beek, P., Planquette, H., and Sarthou, G.: Quantification of trace element atmospheric deposition fluxes to the Atlantic Ocean ( $>40^{\circ} \mathrm{N}$; GEOVIDE, GEOTRACES GA01) during spring 2014, Deep-Sea Res. Pt. I, 119, 34-49, https://doi.org/10.1016/j.dsr.2016.11.010, 2017.

Shelley, R. U., Landing, W. M., Ussher, S. J., Planquette, H., and Sarthou, G.: Regional trends in the fractional solubility of Fe and other metals from North Atlantic aerosols (GEOTRACES cruises GA01 and GA03) following a two-stage leach, Biogeosciences, 15, 2271-2288, https://doi.org/10.5194/bg-15-2271-2018, 2018.

Sutton, J. N., de Souza, G. F., García-Ibáñez, M. I., and De La Rocha, C. L.: The silicon stable isotope distribution along the GEOVIDE section (GEOTRACES GA-01) of the North Atlantic Ocean, Biogeosciences, 15, 5663-5676, https://doi.org/10.5194/bg-15-5663-2018, 2018.

Tang, Y., Castrillejo, M., Roca-Martí, M., Masqué, P., Lemaitre, N., and Stewart, G.: Distributions of total and size-fractionated particulate ${ }^{210} \mathrm{Po}$ and ${ }^{210} \mathrm{~Pb}$ activities along the North Atlantic GEOTRACES GA01 transect: GEOVIDE cruise, Biogeosciences, 15, 5437-5453, https://doi.org/10.5194/bg-15-54372018, 2018.

Tonnard, M., Planquette, H., Bowie, A. R., van der Merwe, P., Gallinari, M., Desprez de Gésincourt, F., Germain, Y., Gourain, A., Benetti, M., Reverdin, G., Tréguer, P., Boutorh, J., Cheize, M., Menzel Barraqueta, J.-L., Pereira-Contreira, L., Shelley, R., Lherminier, P., and Sarthou, G.: Dissolved iron in the North Atlantic Ocean and Labrador Sea along the GEOVIDE section (GEOTRACES section GA01), Biogeosciences Discuss., https://doi.org/10.5194/bg-2018-147, in review, 2018. van Beek, P., Bourquin, M., J.-L., R., Souhaut, M., Charette, M. A., and Jeandel, C.: Radium isotopes to investigate the water mass pathways on the Kerguelen Plateau (Southern Ocean), Deep-Sea Res. Pt. II, 55, 622-637, 2008.

Wischmeyer, A. G., Del Amo, Y., Brzezinski, M., and WolfGladrow, D. A.: Theoretical constraints on the uptake of silicic acid species by marine diatoms, Mar. Chem., 82, 13-29, 2003.

Xu, X., Hulburt, H. E., Schmitz Jr., W. J., Zantopp, R., Fischer, J., and Hogan, J.: On the currents and transports connected with the Atlantic Meridional Overturning Circulation in the subpolar North Atlantic, J. Geophys. Res., 118, 502-516, https://doi.org/10.1002/jgrc.20065, 2013.

Zunino, P., Lherminier, P., Mercier, H., Padín, X. A., Ríos, A. F., and Pérez, F. F.: Dissolved inorganic carbon budgets in the eastern subpolar North Atlantic in the 2000s from in situ data, Geophys. Res. Lett., 42, 9853-9861, https://doi.org/10.1002/2015GL066243, 2015.

Zunino, P., Lherminier, P., Mercier, H., Daniault, N., García-Ibáñez, M. I., and Pérez, F. F.: The GEOVIDE cruise in May-June 2014 reveals an intense Meridional Overturning Circulation over a cold and fresh subpolar North Atlantic, Biogeosciences, 14, 5323-5342, https://doi.org/10.5194/bg-14-5323-2017, 2017.

Zurbrick, C. M., Boyle, E. A., Kayser, R. J., Reuer, M. K., Wu, J., Planquette, H., Shelley, R., Boutorh, J., Cheize, M., Contreira, L., Menzel Barraqueta, J.-L., Lacan, F., and Sarthou, G.: Dissolved $\mathrm{Pb}$ and $\mathrm{Pb}$ isotopes in the North Atlantic from the GEOVIDE transect (GEOTRACES GA-01) and their decadal evolution, Biogeosciences, 15, 4995-5014, https://doi.org/10.5194/bg-154995-2018, 2018. 